INTERNATIONAL ENERGY WORKSHOP

A SUMMARY OF THE 1983 POLL RESPONSES

Alan S. Manne

Department of Operations Research, Stanford University, Stanford, California, USA

Leo Schrattenholzer

International Institute for Applied Systems Analysis, Laxenburg, Austria

RR-85-5

April 1985

Reprinted from The Energy Journal, volume 5 (1984)

INTERNATIONAL INSTITUTE FOR APPLIED SYSTEMS ANALYSIS

Laxenburg, Austria 
Research Reports, which record research conducted at IIASA, are independently reviewed before publication. However, the views and opinions they express are not necessarily those of the Institute or the National Member Organizations that support it.

Reprinted with permission from The Energy Journal, 5(1): 45-64.

Copyright (c) 1984 Oelgeschlager, Gunn \& Hain, Publishers, Inc., Boston, Massachusetts.

All rights reserved. No part of this publication may be reproduced or transmitted in any form or by any means, electronic or mechanical, including photocopy, recording, or any information storage or retrieval system, without permission in writing from the copyright holder.

Printed by Novographic, Vienna, Austria 


\section{PREFACE}

The International Energy Workshop (IEW) is an expanding network of analysts concerned with international energy issues. Jointly created in 1981 by IIASA and Stanford University, the IEW aims to compare published energy projections and to understand the reasons for their divergence. The Workshop process includes iterative polling of projections of crude oil prices, economic growth, primary energy consumption and production, and energy trade. Successive meetings assess the implications of the comparative projections in the presence of most of the poll respondents.

This report by Professor Manne of Stanford University and Dr. Schrattenholzer of IIASA describes the results of the 1983 IEW poll, which served as background to the second meeting of the IEW held at IIASA in June 1983.

HANS-HOLGER ROGNER Leader

Energy Development, Economy, and Investments 


\title{
International Energy Workshop: A Summary of the 1983 Poll Responses
}

\author{
Alan S. Manne* and Leo Schrattenholzer**
}

\section{INTRODUCTION}

Energy forecasting is a hazardous occupation. Virtually any projection is doomed to be incorrect. Opinions can swing from one extreme to another during a six-month period. Our paper is not intended to provide still another projection, but rather to try to explain why different individuals and organizations arrive at divergent views on the long-term energy outlook-and therefore differ on policy decisions.

This paper is an interim report on the current activities of an informally organized group known as the IEW (International Energy Workshop). The general aim is to compare the most up-to-date, long-term energy projections available throughout the world, and to obtain a better understanding of the reasons for their differences. Participation is open to any individual who is prepared to contribute to the aims of the IEW. Usually, such a contribution consists of summarizing one or more energy scenarios by filling in the poll form shown in Appendix Table A-1. The first workshop meeting was held at Stanford University in December 1981, and the second at IIASA (the International Institute for Applied Systems Analysis, Laxenburg, Austria) in June 1983.

The poll covers only items that are comparable in existing international energy statistics: crude-oil prices, GNP growth, primary energy consumption and production, and electricity generation. Typically, the respondents provide a reference case ("surprise-free") scenario. In a few instances, there are disruption and/or alternative growth cases. No probability estimates are assigned to individual projections.

The Energy Journal, Vol. 5, No. 1

Copyright (C) 1984 by the International Association of Energy Economists. All rights reserved.

Presented at the International Energy Workshop, IIASA, June 14-16, 1983, in Laxenburg, Austria.

The individual authors are solely responsible for this analysis, but are indebted to Mark Beltramo, Chris Derstroff, and Tola Minkoff for their suggestions and assistance.

* Department of Operations Research, Stanford University, Stanford, Calif. 94305.

** International Institute for Applied Systems Analysis, A-2361, Laxenburg, Austria. 
Table 1. Number of Responses-IEW Regions

\begin{tabular}{llc}
\hline IEW Regions & Number of Responses \\
\hline 1 & USSR and Eastern Europe & 11 \\
2 & China and other Asian Planned Economies & 10 \\
3 & Centrally Planned Economies & 10 \\
4 & OECD & 28 \\
5 & OPEC & 23 \\
6 & NODC (Non-OPEC Developing Countries) & 20 \\
7 & Market Economies, Subtotal & 22 \\
8 & World, Total & 17 \\
9 & Individual countries/regions, not elsewhere classified & 187 \\
& Total & 328 \\
\hline
\end{tabular}

The poll responses are grouped according to a standardized list of eight world regions and a large miscellaneous category (individual countries/ regions). Table 1 shows the identification of these regions and the number of responses that were received for each. By comparison with the 1981 poll, there has been a significant improvement in IEW coverage of the centrally planned economies and the developing countries. In this brief summary report, we cannot do justice to each of the 328 poll responses that have been received. We can only report our preliminary impressions.

The poll does not require a participant to provide all items shown in Table A-1. Thus, far more responses were received for 1980-2000 than for the year 2010. This suggests that most of these analyses are concerned with short-and intermediate-run decisions (e.g., specific investment projects), rather than with long-term questions (e.g., resource depletion, global carbon dioxide emissions, and technology development). Each type of decision requires a somewhat different time horizon and level of detail.

Table 2 summarizes the total number of responses received for each category. Most participants provided projections of GNP, total primary energy and oil consumption, but fewer included details on the other primary energy sources: natural gas, coal, hydroelectric, geothermal, and nuclear. A still smaller number of the respondents provided estimates for "solar and other renewables." In some instances, estimates for this category were combined with hydroelectric, geothermal, and other sources of energy. Item 17 (electricity generation) was added to the poll at a late date. This may explain why there has been a fairly low response rate on this item. An alternative explanation may be that electricity is "secondary" rather than primary energy, and is therefore not analyzed explicitly in all international energy projections.

Among the 78 respondents, there are governmental and international agencies, oil companies, research institutes, universities, and individuals. 
Table 2. Total Number of Responsesa

\begin{tabular}{lllll}
\hline & 1980 & 1990 & 2000 & 2010 \\
\hline Number of entries for each item: & & & & \\
International price of crude & 220 & 197 & 197 & 72 \\
Real GNP (or GDP) & 251 & 219 & 223 & 73 \\
Total PE consumption & 265 & 233 & 244 & 68 \\
Total PE production & 189 & 184 & 198 & 68 \\
Oil consumption & 274 & 250 & 244 & 72 \\
Oil production & 241 & 243 & 240 & 72 \\
Oil exports-imports & 230 & 247 & 234 & 69 \\
Natural gas consumption & 233 & 202 & 210 & 66 \\
Natural gas production & 192 & 187 & 200 & 66 \\
Natural gas exports-imports & 167 & 180 & 181 & 64 \\
Coal consumption & 233 & 203 & 212 & 68 \\
Coal production & 186 & 181 & 196 & 68 \\
Coal exports-imports & 164 & 177 & 179 & 65 \\
Hydroelectric and geothermal & 224 & 199 & 209 & 67 \\
Nuclear energy & 234 & 208 & 217 & 66 \\
Solar and other renewables & 127 & 124 & 125 & 64 \\
Electricity generation & 127 & 152 & 162 & 57 \\
\hline
\end{tabular}

aTotal number of responses: 328.

Both the "conventional wisdom" and minority viewpoints are represented among the groups shown in Table A-2. Each has been assigned an abbreviation containing three to five alphanumeric characters. For example, the IEA (International Energy Agency) provided both a "high demand" and a "low demand" scenario. These are denoted, respectively, by IEAHD and IEALD

Only a few of these responses are derived directly from formal models. Most are the outcome of judgment and extensive discussions within individual organizations. This type of informal process is flexible and has many other advantages but makes it difficult to trace the reasons for differences between individual projections. We cannot do justice to this issue here but hope to make some progress by the time of the next IEW meeting in June 1985.

\section{POLL RESULTS—INTERNATIONAL OIL PRICES}

Taking all regions together, there are 61 independent projections of the international price of oil for the year 2000. All are reported in currency units of constant purchasing power, and as index numbers with $1980=100$. Index numbers rather than monetary units are used for both oil prices and GNP. This avoids some definitional problems, and increases the comparability of the poll responses. 


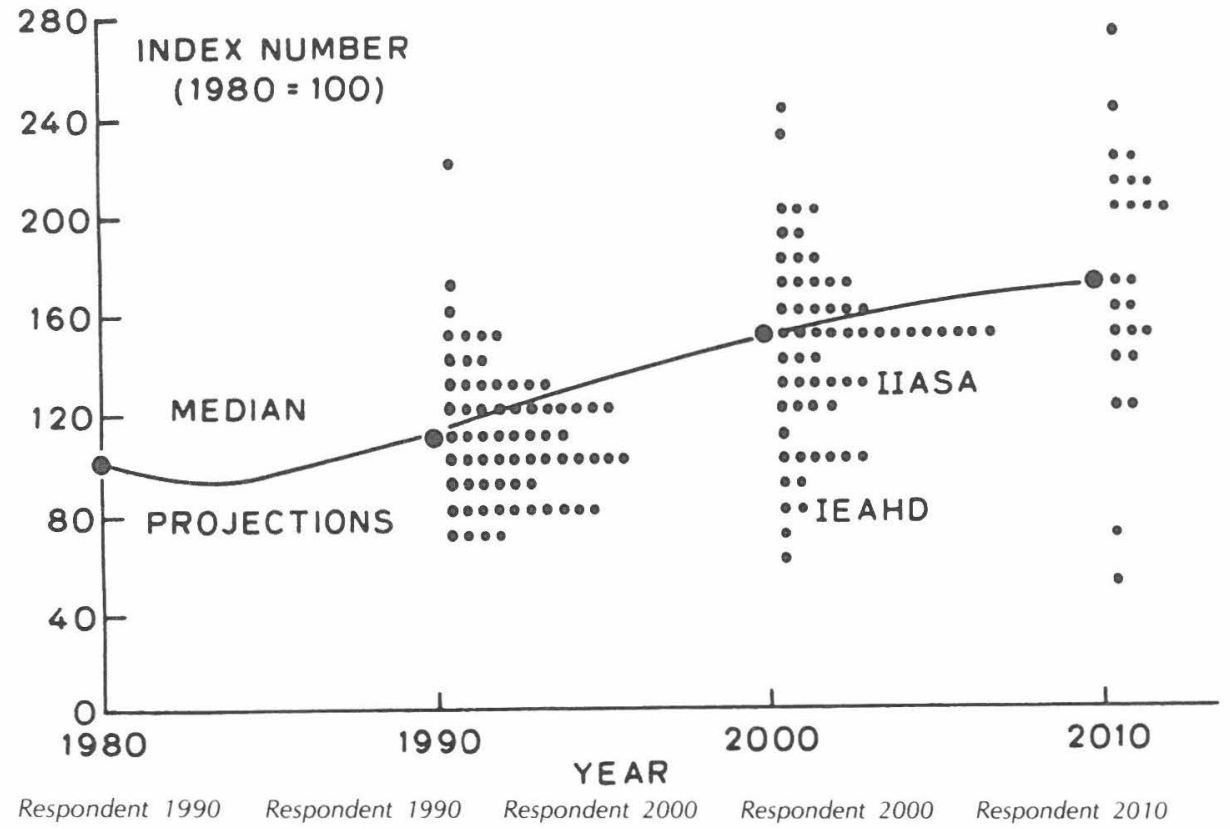

\begin{tabular}{|c|c|c|c|c|c|c|c|c|c|}
\hline respb & 223 & criep & 110 & stols & 240 & criep & 148 & bnl & 266 \\
\hline ipe & 173 & tea & 109 & ipe & 229 & DRIE & 147 & iemf & 243 \\
\hline trac 3 & 164 & smil & 105 & dnmoe & 201 & DOE & 146 & etsld & 225 \\
\hline stols & 155 & cal & 102 & etsld & 200 & czmoe & 146 & cerg & 215 \\
\hline obenb & 150 & assu & 102 & cecct & 199 & tea & 141 & pilot & 213 \\
\hline obena & 150 & polas & 100 & $\mathrm{mkr}$ & 191 & swea & 141 & fsz & 213 \\
\hline etsld & 150 & merz & 100 & nzmoe & 188 & iiasa & 139 & DOE & 213 \\
\hline ceoct & 141 & jaeri & 100 & ewrsi & 182 & ift & 135 & par & 200 \\
\hline iiasa & 139 & hnpb & 100 & iemf & 181 & emcn & 135 & nzmoe & 200 \\
\hline nzmoe & 138 & DRIE & 99 & fsz & 181 & ieald & 132 & criep & 199 \\
\hline $\mathrm{mkr}$ & 134 & $3 r t$ & 99 & obenb & 175 & cal & 131 & opecl & 196 \\
\hline iemf & 134 & ieald & 98 & obena & 175 & smil & 130 & jaeri & 175 \\
\hline esc & 134 & cec & 97 & bph & 175 & merz & 130 & etshd & 175 \\
\hline atw & 134 & pilot & 96 & bnl & 172 & assu & 122 & assu & 165 \\
\hline par & 130 & respa & 94 & doe & 168 & paec & 122 & tea & 164 \\
\hline ewrsi & 128 & eia & 94 & esc & 163 & polas & 120 & smil & 150 \\
\hline wbk & 126 & ece & 92 & $3 r t$ & 161 & respi & 117 & polas & 150 \\
\hline swea & 125 & cerg & 90 & par & 160 & hnpb & 110 & leob & 150 \\
\hline etshd & 125 & eni & 86 & cerg & 160 & bpl & 105 & ift & 144 \\
\hline dnmoe & 125 & ceceu & 86 & pilot & 157 & iea83 & 103 & iiasa & 139 \\
\hline gri & 125 & trac2 & 85 & emch & 156 & seri & 100 & paec & 122 \\
\hline stohs & 122 & cies1 & 85 & wbk & 154 & oriea & 100 & hnpb & 120 \\
\hline ift & 120 & cies & 85 & smie2 & 154 & ceceu & 97 & ciesl & 68 \\
\hline bph & 120 & ieahd & 82 & smie1 & 154 & сесcр & 97 & ciesh & 50 \\
\hline fsz & 119 & DOE & 81 & gri & 153 & cec & 93 & & \\
\hline cecfic & 118 & leob & 80 & respa & 153 & cecfc & 88 & & \\
\hline trac1 & 116 & iee & 79 & stohs & 150 & respb & 84 & & \\
\hline emch & 116 & bnl & 78 & leob & 150 & ieahd & 82 & & \\
\hline doe & 115 & iea83 & 77 & jaeri & 150 & ciesl & 73 & & \\
\hline czmoe & 115 & сесср & 76 & etshd & 150 & ciesh & 62 & & \\
\hline candd & 110 & ciesh & 75 & opecl & 148 & & & & \\
\hline paec & 110 & bpl & 75 & & & & & & \\
\hline opecl & 110 & shell & 73 & & & & & & \\
\hline emcn & 110 & respi & 71 & & & & & & \\
\hline
\end{tabular}

Figure 1. International price of crude oil $(1980=100)$. 
The individual oil-price estimates differ widely -in extreme cases by a factor of three. Each estimate is shown as a dot in a frequency distribution (Figure 1). With only a few exceptions, the respondents indicated that real oil prices will rise from their 1980 level-and at a more rapid rate during the 1990s than during the 1980s. Typically, this reflects the view that those forces leading to price increases (demands increased by economic growth and supplies reduced because of the gradual exhaustion of conventional oil and gas resources) will be stronger than those exerting downward pressure on oil prices (conservation responses to the events of the 1970s and the introduction of alternative forms of energy supply). The median value of all responses is 148 in 2000, equivalent to an average annual price increase of 2.0 percent from 1980 onward. Clearly this result is incompatible with the view that the 1983 oil glut was a "structural" phenomenon, and that low prices will persist indefinitely.

With a little detective work, it is possible to narrow the range of the possibilities considered here. For example, one of the lowest responses is IEAHD. This represents a "what if?" scenario. The IEA assumes that real oil prices will decline between 1980 and 1985, and then will remain stable through 2000. Under these circumstances, oil demand is stimulated and begins to exceed supplies during the 1990s. This represents an instructive thought experiment showing the consequence of "too low" an oil price, but it is not a logically consistent scenario. By contrast, consider the same organization's low-demand case (IEALD). Through side calculations, it can be shown that the IEA's global supply-demand gap would have been reduced to zero if the agency had assumed a price level that is close to the poll median results.

Here is a second example of analytic structure determining the poll response. Underlying IIASA's 1981 publication Energy in a Finite World was a good deal of optimism on the costs and speed of market penetration of synthetic fuels. It was believed that tar sands, shale oil or coal-based synfuels could expand rapidly in North America, and that their costs would be about 40 percent higher (in real terms) than the 1980 price of crude oil. This explains why IIASA's initial poll response (the "low" scenario of 1981) indicates a 1990 crude-oil price index of 139 (with $1980=100$ ) and why the index remains at that level through 2010. In effect, synthetic fuels serve as an international "backstop" technology in the original study. This leads to stable world oil prices-and no increase in the OECD region's net demand for oil imports. More recent IIASA calculations (identified as IIA83) have arrived at somewhat different conclusions.

Through the IEW process, we hope to systematize this type of analysis. Each participant is urged to provide conjectures as to why stated projections deviate from the poll medians. Some of the deviation may turn out to be errors in reporting or transcription. Others may be connected with 
definitional differences in regional or product coverage. In other cases, there may be explanations that can be related directly to model structure. Another round of polls and discussions would help to distinguish the effects of assumptions, statistical categories, and analytic features.

Cynics will be quick to point to other possible explanations for these differences. Long-term projections may be heavily influenced by current events. For example, there was an oil glut during the 18 months that elapsed between the 1981 and 1983 workshops. Between these two polls, the median oil-price projection for the year 2000 declined from 175 to 148 (in real terms, with $1980=100$ ). The statistical significance of this result is a bit doubtful, because the sample was not identical in both cases. Moreover, one would expect this type of decline if oil prices are following a random-walk pattern. Through autocorrelation, projected prices are then affected by the current level. Nonetheless, the cynics may be right. Just as in macroeconomic forecasting, there is a strong herd instinct that operates within the community of energy analysts. In any case, the workshop process is bound to lead to healthy introspection-and more attention to minority viewpoints.

\section{IMPORTS AND EXPORTS-OIL AND GAS}

Because oil is a liquid, it can be transported at lower specific costs than either natural gas or coal. Until the distant future date when there are large-scale movements of methanol and/or hydrogen, it is generally believed that oil will retain its present position as the principal fuel in international trade. Because oil constitutes a "swing" fuel, small differences in a region's total energy production or consumption can lead to large percentage changes in the quantities of oil imported or exported.

Measurement problems turn out to be quite serious when we attempt to compare oil import and export projections. Within the OECD region, for example, there are wide discrepancies between the individual responses for the statistical base year of 1980 (Figure 2). These differences account for some of the range in import projections in subsequent years. The discrepancies in measurement are probably more significant than the changes in the median. It would be useful to determine how much of these differences can be traced to statistical difficulties in distinguishing between crude oil and refined products, and how much is attributable to other factors, such as processing losses, stock changes, and bunkers.

Figure 3 summarizes the workshop's median estimates of interregional shipments of oil and gas. (Coal shipments are insignificant at this level of regional aggregation. A more detailed geographical breakdown is needed in order to analyze coal trade.) The poll provides an automatic global 
consistency check between independent estimates of interregional trade. From the positive and negative entries in Figure 3, we find that the export and import totals are in reasonably close balance. Looking at the poll responses on a nation-by-nation basis, however, there is evidence that the growth in NODC oil imports may be understated.

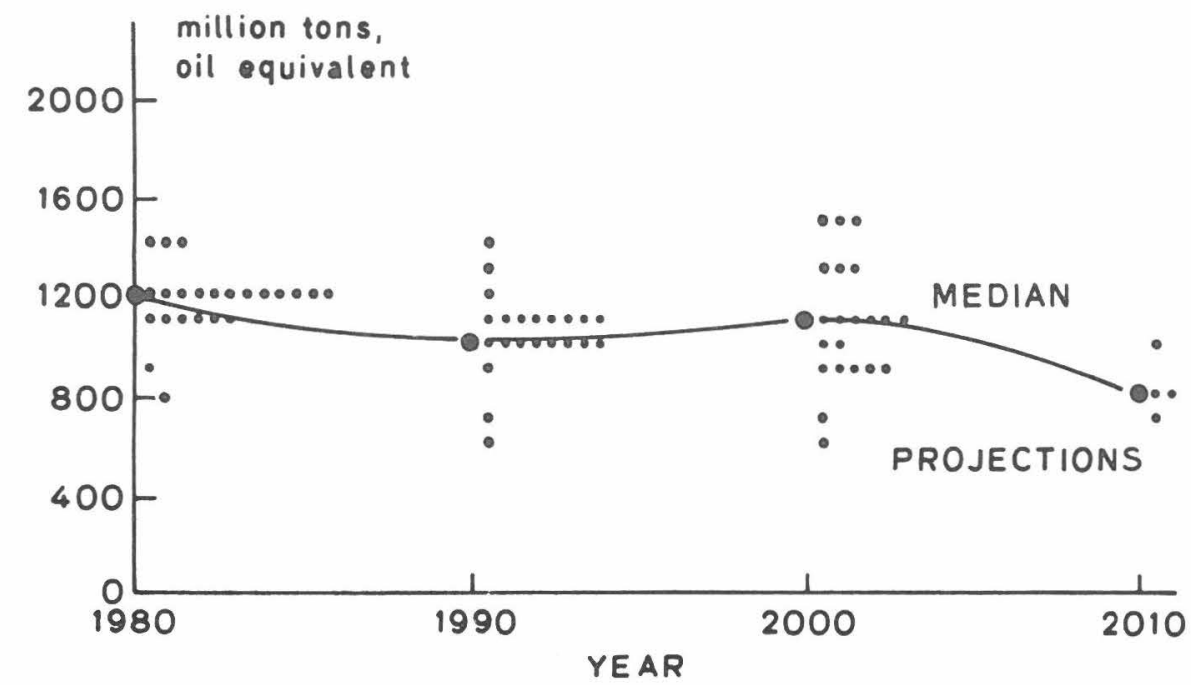

\begin{tabular}{|c|c|c|c|c|c|c|c|}
\hline $\begin{array}{l}\text { Respondent } \\
\text { sohn }\end{array}$ & $\begin{array}{l}1980 \\
1442\end{array}$ & $\begin{array}{l}\text { Respondent } \\
\text { stohs }\end{array}$ & $\begin{array}{l}1990 \\
1395\end{array}$ & $\begin{array}{l}\text { Respondent } \\
\text { aohn }\end{array}$ & $\begin{array}{r}2000 \\
1499\end{array}$ & $\begin{array}{l}\text { Respondent } \\
\text { opecl }\end{array}$ & $\begin{array}{l}2010 \\
1050\end{array}$ \\
\hline stols & 1360 & sohn & 1253 & oriea & 1475 & iiasa & 842 \\
\hline stohs & 1360 & $b p h$ & 1190 & ieahd & 1454 & cerg & 805 \\
\hline opecl & 1210 & ieahd & 1140 & stohs & 1310 & $D O E$ & 725 \\
\hline$D O E$ & 1185 & gulfb & 1125 & gulfb & 1285 & & \\
\hline ipe & 1181 & respa & 1112 & bph & 1267 & & \\
\hline cerg & 1181 & $w b k$ & 1109 & opecl & 1145 & & \\
\hline ieald & 1180 & opecl & 1107 & ind & 1145 & & \\
\hline ieahd & 1180 & eni & 1094 & $w b k$ & 1122 & & \\
\hline iea83 & 1180 & stols & 1090 & iea83 & 1113 & & \\
\hline$b p /$ & 1171 & iea83 & 1068 & con & 1087 & & \\
\hline$b p h$ & 1171 & $D O E$ & 1025 & ipe & 1056 & & \\
\hline gulfb & 1170 & cerg & 1020 & cerg & 993 & & \\
\hline$w b k$ & 1155 & ipe & 1015 & $3 r t$ & 980 & & \\
\hline ind & 1155 & respc & 1010 & $D O E$ & 935 & & \\
\hline eni & 1148 & ind & 1010 & respa & 896 & & \\
\hline con & 1144 & con & 995 & stols & 875 & & \\
\hline respc & 1135 & ieald & 975 & ieald & 872 & & \\
\hline respb & 1112 & $b p l$ & 974 & $b p l$ & 872 & & \\
\hline respa & 1112 & $3 r t$ & 940 & iiasa & 726 & & \\
\hline $3 r t$ & 1085 & iiasa & 712 & respb & 613 & & \\
\hline oriea & $\begin{array}{l}876 \\
797\end{array}$ & respb & 608 & & & & \\
\hline iiasa & 797 & & & & & & \\
\hline
\end{tabular}

Figure 2. OECD oil imports (mtoe). 


\section{2 / The Energy Journal}

During 1980, the CPE (centrally planned economies) maintained net exports of oil to the market economies, but these quantities were quite small in relation to OPEC's export volume. According to most of the poll participants, there will be a declining trend of net oil exports from the $\mathrm{CPE}$, and they might become net importers of oil by the year 2000. Even at that point, the CPE will be largely self-sufficient in energy, and will substantially increase their gas exports to the OECD. International energy markets will continue to be dominated by the oil trade between just regions-OPEC and the OECD.

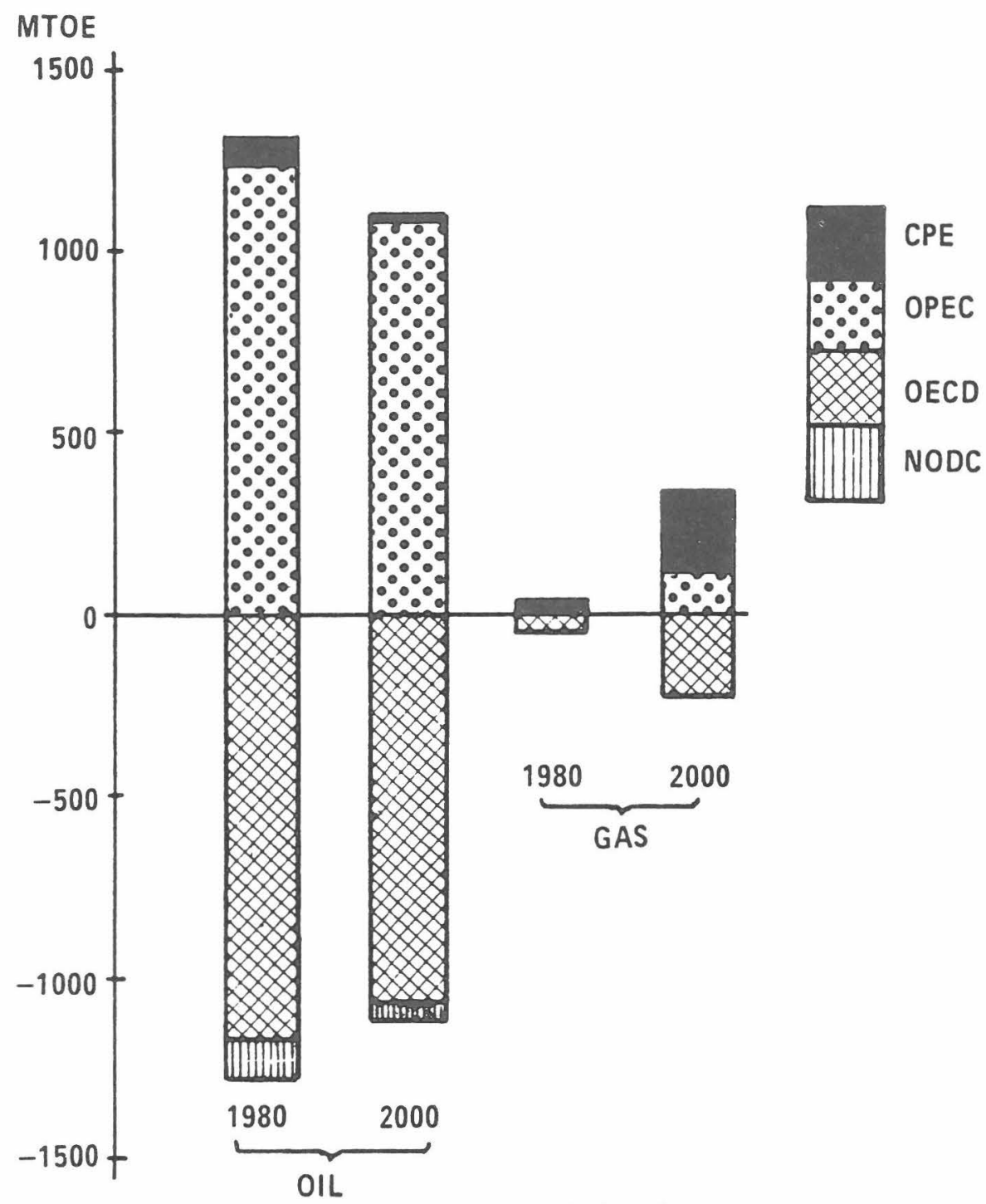

Figure 3. Exports-imports of oil and gas (mtoe). 
NODC (non-OPEC developing countries) oil imports will depend upon their income growth and their balance-of-payment constraints. There is a diversity of opinion on whether these countries will choose to expand their domestic oil production, or whether they will shift to less energy-intensive lines of development than in the past. Very few of the poll participants have projected that the NODC group as a whole will be importing significantly more oil in the year 2000 than in 1980 . The median indicates a decline. In assessing the significance of these results, it would be helpful to have more analysis undertaken by the NODCs themselves. Their research organizations are underrepresented within the poll.

\section{ENERGY CONSERVATION, INTERFUEL SUBSTITUTION, AND RENEWABLE ENERGY}

Figures 4 and 5 provide a global view of the median poll responses for 1980 and 2000 on total primary energy consumption and its breakdown into individual fuels. Each pair of bar charts summarizes one region's prospects for interfuel substitution and for energy conservation. These forces do not operate in an autonomous way. They are a direct consequence of the two oil-price shocks of the 1970s-together with the expectation of further oil-price increases.

Except for OPEC, it is projected that total primary energy demands will increase less than in proportion to economic growth. Conservation is defined here as a residual - the difference between the projected energy consumption in 2000 and the demands that would have occurred if the energy-GNP ratio had remained constant from 1980 on. Thus, conservation represents the combined effect of improved technical efficiencies and of changes in the economy's product mix.

The overall reduction in the energy-GNP ratio (expressed in terms of primary energy equivalent) is indicated by the conservation component at the top of each region's bar for the year 2000. In both centrally planned and market economies, conservation represents the largest single source of additional energy supplies for 2000 . This was once a heresy, but is apparently the prevailing view today.

Interfuel substitution plays a vital role in explaining why virtually all organizations project significant GNP growth, despite little or no increase in global oil supplies. Natural gas, coal, and nuclear energy provide the principal sources of interfuel substitution, although their relative contributions vary from one respondent to another. A major increase in natural gas production is anticipated only within OPEC and the USSR.

There is general agreement that only a small contribution will be provided by the renewables: hydroelectric, solar, and biomass. This outcome of the poll may be attributed to the inherent limitations of technologies 


\section{4 / The Energy Journal}

based on dispersed energy sources. It may also be attributed to definitional differences, because the 1980 base year responses vary quite erratically from one respondent to another. Clearly, it would be worthwhile to standardize these definitions and statistics. In any event, the IEW poll cannot be expected to resolve the highly charged controversy surrounding the renewables and the role that they might play as alternatives to coal and nuclear energy.

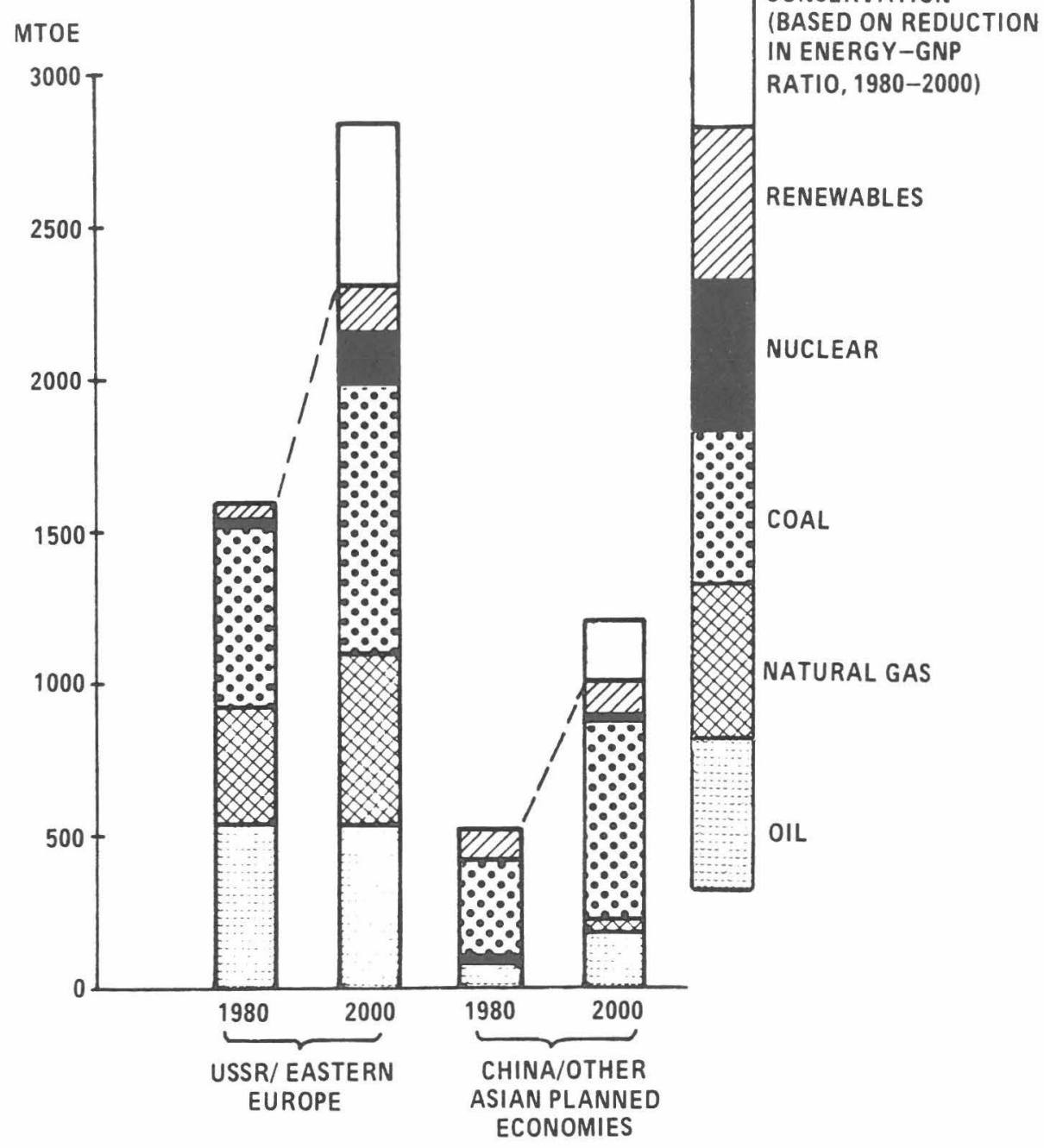

Figure 4. Total primary energy consumption-poll medians-centrally planned economies (mtoe). 


\section{WHY DO ENERGY PROJECTIONS DIFFER?}

The following list offers reasons why energy projections may differ from one another. No single factor explains all of the differences.

Errors in recording and transcribing; 1980 statistics;

Date of projection;

Time horizon of projection;

Definitional problems;

Model structure;

Demand parameters, such as GNP growth, structural changes, regulatory approaches to conservation, price and income effects, final vs. primary energy demands, and the role of electricity;

Supply parameters, such as conventional resources (geological resource base, producibility constraints) and unconventional fuels (costs and speed of market penetration;

Philosophical differences, and

"Stake-Holders": detailed information vs. inherent biases.

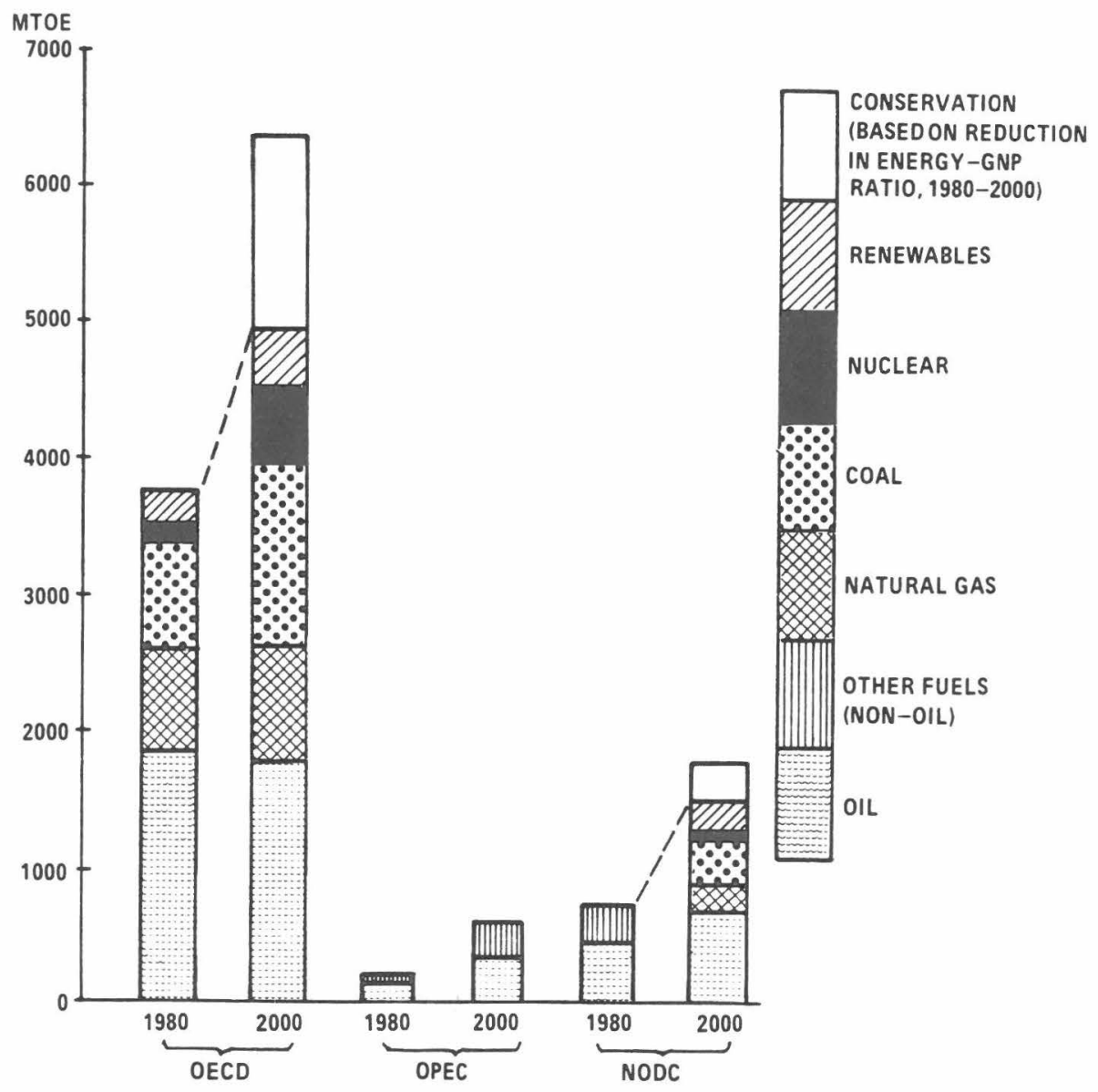

Figure 5. Total primary energy consumption-poll medians-market economies (mtoe). 
First, there can be errors in recording and transcribing the poll entries. We have tried to be vigilant about this. Although confident that transcription errors are not a significant source of the differences reported here, we cannot guarantee to have detected all errors. Iterative polling can be helpful in identifying errors, and in reducing the differences between base-year (1980) statistical measurements.

The date of projection is a crucial element in attempting to understand why these estimates differ. Recent forecasters are not necessarily wiser than earlier ones, but at least they can take advantage of autocorrelation in the random-walk pattern that seems characteristic of energy time series.

The time horizon of the projection may also be a significant element. There is some evidence that the longer the time horizon, the lower the forecast of the total level of energy demands and the higher are oil prices.

Definitional problems are a major source of the discrepancies between individual projections. It is disturbing to see the wide range of variations in base-year (1980) statistics. Some of these variations are attributable to differences in the date of projection.

It is an open issue whether model structure (whether formal or implicit) can explain a large part of the variation in poll responses. Our personal conjecture is that far less is explained by structure than by differences in the numerical assumptions related to supply-and-demand scenarios. Additional work is needed in order to check this conjecture.

Uncertainties in GNP growth are frequently cited as a critical element in demand forecasting. Over the long term, however, these may be less significant than differences in price elasticities of demand, or in the response of individual energy consumers to centralized regulations that are designed to conserve energy.

Scenario assumptions may be equally critical on the supply side of international energy markets. Over the next two decades, it is not the ultimate resource base, but rather the producibility constraints (e.g., leasing and depletion policies) that will determine how rapidly the world's nonrenewable resources will be exploited. Moreover, international crises and supply disruptions may occur at any moment. These events cannot easily be predicted by conventional economic analysis.

In all of this, perhaps the most elusive factors are philosophical and ideological. "Stake-holders" have more detailed information available, but have an obvious interest in exaggerating the prospective rate of market penetration by their group's specific technology. Similarly, political leaders are prone to adopt optimistic targets for their nation's or region's GNP growth. Another factor is the personality of the individual forecaster. Some have an inclination to focus upon good news, and others prefer to predict that doomsday is at hand. (These two attitudes seem to be the psychological opposite of the "herd instinct.") 
In short, there are many imponderable elements that may even unconsciously influence projections. But we also believe the converse to be true-that the IEW may exert an influence on these factors. The polling process cannot eliminate biases, but can at least contribute to greater awareness of their existence.

On balance, we believe that long-term energy projections are essential for both the public and private sectors of the world's economies. Rational decisions cannot be based on scenarios that fail the test of logical consistency. Individual projections will continue to differ, but it is worthwhile to attempt to understand why.

\section{POSTSCRIPT ON THE DELPHI TECHNIQUE}

The Delphi technique and the IEW process have elements in common, but there are distinct differences. Both entail iterative polling, which may lead to "cuing" and to an artificial consensus. And there may be unconscious biases in the selection of poll participants.

There are, however, the following key differences:

1. The IEW poll does not ask respondents for their personal opinions, but rather for their organization's most recent set of published projections. Written documents provide a more objective record than informal opinions and thereby make a systematic difference in the results.

2. Each respondent is asked to fill in a supplementary questionnaire that is designed to elicit-information on the method of projection, reasons for differences from poll medians, and critical uncertainties in the international energy outlook. Again, this enhances the reproducibility of poll results.

3. Except for a few cases where anonymity is essential (e.g., as a consequence of US antitrust laws), the individual poll respondents are identified.

4. Face-to-face meetings are an essential part of the IEW process.

Workshop sessions are more expensive than remote polling, but these meetings appear far more effective in identifying the reasons for differences in projections. On international energy issues, it is just as important to understand these differences as to arrive at a logically consistent consensus. And we cannot expect any certainty other than the inevitability of surprise. 


\section{APPENDIX TABLES}

A-1. IEW poll form, IIASA, 1983

A-2. IEW poll respondents

Other appendix tables, frequency distributions of region-by-region energy-GNP ratios, identification of individual countries/regions, individual response forms, and frequency distributions of responses are available in the form of a computer printout (approximately 600 pages) and a magnetic tape. For further information, please write to Leo Schrattenholzer at IIASA. Frequency distributions are also available for individual countries/regions. 
Table A-1. International Energy Workshop Poll, IIASA, 1983

Country/Region:

Organization/project:

Reference (including date) of most recent report:

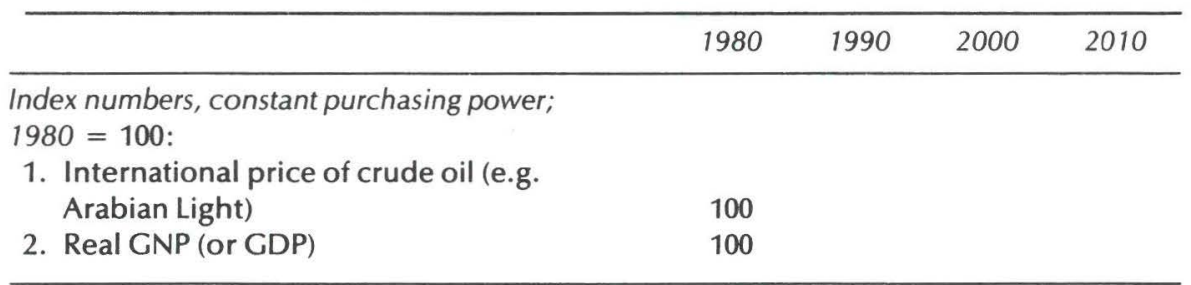

Primary energy, million tons of oil equivalent (mtoe)a

3. Total consumption

4. Total production

5. Oil, consumption $b$

6. Oil, production ${ }^{b}$

7. Oil, exports-imports ${ }^{b}$

8. Natural gas, consumption

9. Natural gas, production

10. Natural gas, exports-imports

11. Coal, consumption ${ }^{c}$

12. Coal, production

13. Coal, exports-imports ${ }^{c}$

14. Hydroelectric and geothermal

15. Nuclear energy

16. Solar and other renewables

17. Electricity generation (tkWh)

aUseful approximations: $\begin{aligned} 1 \mathrm{mtoe} / \text { year } & =10^{13} \mathrm{kilocalories} \\ 0.65 \mathrm{mtoe} / \text { year } & =1 \mathrm{million} \text { tons coal } / \text { year } \\ 50 \mathrm{mtoe} / \text { year } & =1 \mathrm{million} \text { barrels daily } \\ 23 \mathrm{mtoe} / \text { year } & =1 \text { quad BTU/year }\end{aligned}$

bOil includes natural gas liquids, unconventional oils, and synthetics based on tar sands and shale oil.

${ }^{c}$ Coal includes solid fuels such as lignite and peat. Includes coal consumed for manufacture of synthetic fuels. 
Table A-2. IEW Poll Respondents

\begin{tabular}{|c|c|c|c|}
\hline \multicolumn{2}{|c|}{ Organization/project } & \multirow{2}{*}{$\begin{array}{l}\text { Last Year } \\
\text { Reported } \\
2010\end{array}$} & \multirow{2}{*}{$\begin{array}{l}\begin{array}{c}\text { Country/Region } \\
\text { Coverage }\end{array} \\
\text { USSR }\end{array}$} \\
\hline ASSU & $\begin{array}{l}\text { Academy of Sciences of the USSR, } \\
\text { June } 1983\end{array}$ & & \\
\hline ATW & $\begin{array}{l}\text { Forschungsgesellschaft für alterna- } \\
\text { tive Technologien und Wirt- } \\
\text { schaftsanalysen (ATW), Univer- } \\
\text { sity of Regensburg, October } 1982\end{array}$ & 1990 & $\begin{array}{l}\text { Brazil, India, } \\
\text { Kenya, Malaysia }\end{array}$ \\
\hline BNL & $\begin{array}{l}\text { Brookhaven National Laboratory, } \\
1983 \text { (forthcoming) }\end{array}$ & 2010 & U.S.A. \\
\hline $\mathrm{BPH}, \mathrm{BPL}$ & $\begin{array}{l}\text { British Petroleum-high- and low- } \\
\text { growth cases, December } 1982\end{array}$ & 2000 & 4-7; OECD Europe \\
\hline BPPTK & $\begin{array}{l}\text { Badan Pengkajian dan Penerapan } \\
\text { Teknologi (BPP Teknologi), } \\
\text { December } 1980\end{array}$ & 2010 & Indonesia \\
\hline $\mathrm{CAL}$ & $\begin{array}{l}\text { Standard Oil Company of Cali- } \\
\text { fornia, June } 1982\end{array}$ & 2000 & 4 \\
\hline CANDD & $\begin{array}{l}\text { CANDIDE Model, Economic Coun- } \\
\text { cil of Canada, September } 1982\end{array}$ & 1990 & Canada \\
\hline $\begin{array}{l}\text { CECCP, CECEU } \\
\text { CECFC, CEC, } \\
\text { CECCT }\end{array}$ & $\begin{array}{l}\text { Commission of the European Com- } \\
\text { munities-Cooperation, Europe, } \\
\text { and Free Competition scenarios, } \\
\text { and results identical for all } 3 \text { scen- } \\
\text { arios, June 1983; Candidate Tech- } \\
\text { nologies scenario, March } 1982\end{array}$ & 2000 & $\begin{array}{l}\text { Belgium, Denmark, } \\
\text { Federal Republic of } \\
\text { Germany, France, } \\
\text { Greece, Ireland, } \\
\text { Italy, Luxembourg, } \\
\text { The Netherlands, } \\
\text { United Kingdom }\end{array}$ \\
\hline CERG & $\begin{array}{l}\text { Cambridge Energy Research } \\
\text { Group (UK), R. J. Eden, }\end{array}$ & 2010 & $\begin{array}{l}\text { 4-7; U.S.A. and } \\
\text { Canada; Japan, } \\
\text { Australia and New } \\
\text { Zealand; Western } \\
\text { Europe }\end{array}$ \\
\hline $\begin{array}{l}\text { CIES, CIESH, } \\
\text { CIESL }\end{array}$ & $\begin{array}{l}\text { Center for International Energy } \\
\text { Studies, Erasmus University- } \\
\text { OECD Europe, high-, and low- } \\
\text { growth estimates, August } 1982\end{array}$ & 2010 & 8; OECD Europe \\
\hline $\mathrm{CON}$ & Conoco, January 1983 & 2000 & 4,$7 ;$ U.S.A. \\
\hline CPC & $\begin{array}{l}\text { Chinese Petroleum Corporation, } \\
\text { February } 1982\end{array}$ & 2000 & Taiwan \\
\hline CRIEP & $\begin{array}{l}\text { Central Research Institute of Elec- } \\
\text { tric Power Industry, } 1982\end{array}$ & 2010 & Japan \\
\hline CZMOE & $\begin{array}{l}\text { Czechoslovakian Federal Ministry } \\
\text { of Fuel and Energy, } 1983\end{array}$ & 2000 & Czechoslovakia \\
\hline DNMOE & Danish Ministry of Energy, 1983 & 2000 & Denmark \\
\hline DOE82 & $\begin{array}{l}\text { U.S. Department of Energy, Office } \\
\text { of Policy, Planning, and Analysis, } \\
\text { and Analysis, July } 1982\end{array}$ & 2000 & 5,7 \\
\hline DOE & $\begin{array}{l}\text { U.S. Department of Energy, Office } \\
\text { of Policy, Planning, and Analysis, } \\
\text { July } 1983\end{array}$ & 2010 & $3,4,6 ;$ U.S.A. \\
\hline
\end{tabular}


Table A-2. IEW Poll Respondents (Continued)

\begin{tabular}{|c|c|c|c|}
\hline \multicolumn{2}{|c|}{ Organization/project } & \multirow{2}{*}{$\begin{array}{c}\text { Last Year } \\
\text { Reported }\end{array}$} & \multirow{2}{*}{$\begin{array}{c}\begin{array}{c}\text { Country/Region } \\
\text { Coverage }\end{array} \\
\text { Western Europe }\end{array}$} \\
\hline DRIE & DRI Europe, March 1983 & & \\
\hline ECE & $\begin{array}{l}\text { U.N. Economic Commission for } \\
\text { Europe, General Energy Unit } \\
\text { and Projections and Program- } \\
\text { ming Division, } 1982\end{array}$ & 1990 & $\begin{array}{l}\text { USSR; Western } \\
\text { Europe, Eastern } \\
\text { Europe, North } \\
\text { America, Total of } \\
\text { ECE Regions }\end{array}$ \\
\hline EEF & $\begin{array}{l}\text { U.N. Economic Commission for } \\
\text { Europe, General Energy Unit, } \\
\text { "An Efficient Energy Future," } \\
\text { March } 1983\end{array}$ & 2000 & $1 ;$ U.S.A \\
\hline EIA & $\begin{array}{l}\text { U.S. Energy Information Adminis- } \\
\text { tration, } 1990 \text { Midprice Scenario, } \\
1983\end{array}$ & 1990 & $\begin{array}{l}4,5,7 ; \text { U.S.A.; } \\
\text { Non-U.S.OECD, } \\
\text { Developing } \\
\text { Countries }\end{array}$ \\
\hline $\mathrm{EMCH}$ & $\begin{array}{l}\text { ETA-MACRO: China; A.S. Manne, } \\
\text { Stanford University November } \\
1982\end{array}$ & 2000 & 2 \\
\hline EMCN & $\begin{array}{l}\text { ETA-: Canada; J.S. Rogers and } \\
\text { T.F. Wilson, University of } \\
\text { Toronto, May } 1983\end{array}$ & 2000 & Canada \\
\hline ENI & $\begin{array}{l}\text { Ente Nazionale Idrocarburi (ENI), } \\
\qquad 1983\end{array}$ & 1990 & 4 \\
\hline ESC & $\begin{array}{l}\text { Energy Study Centre, January } \\
\qquad 1983\end{array}$ & 2000 & The Netherlands \\
\hline ETSHD, ETSLD & $\begin{array}{l}\text { Energy Technology Systems } \\
\text { Analysis Project of the Inter- } \\
\text { national Energy Agency-High- } \\
\text { and low-demand cases, } 1983 \\
\text { (forthcoming). }\end{array}$ & 2010 & $\begin{array}{l}\text { Australia, Austria, } \\
\text { Belgium, Federal } \\
\text { Republic of } \\
\text { Germany, Ireland, } \\
\text { Italy, Japan, The } \\
\text { Netherlands, } \\
\text { Norway, Spain, } \\
\text { Sweden, Switzer- } \\
\text { land, United } \\
\text { Kingdom, United } \\
\text { States; Sum of the } \\
\text { above } 14 \text { countries }\end{array}$ \\
\hline EWRSI & $\begin{array}{c}\text { The East-West Center, Resource } \\
\text { Systems Institute, Energy and } \\
\text { Industrialization Project, } 1982\end{array}$ & 2000 & $\begin{array}{l}\text { Bangladesh, India, } \\
\text { Pakistan, Papua } \\
\text { New Guinea, Philip- } \\
\text { pines, Singapore, } \\
\text { South Korea, Sri } \\
\text { Lanka, Thailand }\end{array}$ \\
\hline FSZ & $\begin{array}{l}\text { J.D. Fuller, S.D. Schwartz, and } \\
\text { W.T. Ziemba, University of } \\
\text { British Columbia, Fall } 1982\end{array}$ & 2010 & Canada \\
\hline GRI & $\begin{array}{l}\text { Gas Research Institute, September } \\
1983\end{array}$ & 2000 & U.S.A. \\
\hline
\end{tabular}


Table A-2. IEW Poll Respondents (Continued)

\begin{tabular}{|c|c|c|c|}
\hline \multicolumn{2}{|c|}{ Organization/project } & \multirow{2}{*}{$\begin{array}{c}\text { Last Year } \\
\text { Reported }\end{array}$} & \multirow{2}{*}{$\begin{array}{l}\quad \begin{array}{c}\text { Country/Region } \\
\text { Coverage }\end{array} \\
\text { 4-7; U.S.A., } \\
\text { Canada, Japan; } \\
\text { Western Europe, } \\
\text { Developing } \\
\text { Countries }\end{array}$} \\
\hline $\begin{array}{l}\text { GULFB, GULFS, } \\
\text { GULFL }\end{array}$ & $\begin{array}{l}\text { Gulf Oil Corporation, Economics } \\
\text { Division-Baseline, Supply Dis- } \\
\text { ruption and Low Economic } \\
\text { Growth scenarios, February } 1983\end{array}$ & & \\
\hline HNPB & $\begin{array}{l}\text { Hungarian National Planning } \\
\text { Board-Energy Modeling Group, } \\
1983\end{array}$ & 2010 & Hungary \\
\hline IAEAH, IAEAL & $\begin{array}{l}\text { International Atomic Energy } \\
\text { Agençy-high- and low-con- } \\
\text { sumption estimates, September } \\
1982\end{array}$ & 2000 & $\begin{array}{l}\text { 1, 4, 8; OECD North } \\
\text { America, OECD } \\
\text { Europe, OECD } \\
\text { Pacific, Asia, Latin } \\
\text { America, Africa and } \\
\text { Middle East; Indus- } \\
\text { trialized Countries; } \\
\text { Developing } \\
\text { Countries }\end{array}$ \\
\hline $\begin{array}{l}\text { IEA, IEAHD, } \\
\text { IEALD }\end{array}$ & $\begin{array}{l}\text { International Energy Agency- } \\
\text { Midpoints, high-and low-demand } \\
\text { scenarios, October } 1982\end{array}$ & 2000 & 4-6; USSR \\
\hline IEA83 & $\begin{array}{l}\text { International Energy Agency- } \\
\text { Low-demand scenario, June } 1983\end{array}$ & 2000 & 4 \\
\hline IEE & $\begin{array}{l}\text { Institute of Energy Economics, } \\
\text { Japan, December } 1982\end{array}$ & 1990 & Japan \\
\hline IEMF & $\begin{array}{l}\text { Israel Energy Modeling Forum, } \\
\text { July } 1982\end{array}$ & 2010 & Israel \\
\hline IFT & $\begin{array}{l}\text { Institute for Future Technology, } \\
1982\end{array}$ & 2010 & Japan \\
\hline IIASA, IIA83 & $\begin{array}{l}\text { International Institute for Applied } \\
\text { Systems Analysis, 1981; also } 1983\end{array}$ & 2010 & $\begin{array}{l}1-4,7-8 ; \text { Aggregate } \\
\text { of IIASA regions } 4 \\
\text { and } 5, \text { IIASA region } \\
6\end{array}$ \\
\hline IND & $\begin{array}{l}\text { Standard Oil Company of Indiana, } \\
\text { May } 1983\end{array}$ & 2000 & $\begin{array}{l}\text { 1-8; Aggregate of } \\
\text { Israel, Yugoslavia, } \\
\text { and South Africa }\end{array}$ \\
\hline INET & $\begin{array}{l}\text { Institute of Nuclear Energy Tech- } \\
\text { nology, Quinghua University, } \\
\text { Beijing, December } 1981\end{array}$ & 2000 & 2 \\
\hline IPE & $\begin{array}{l}\text { IPE Model; N. Choucri, Massa- } \\
\text { chusetts Institute of Technology, } \\
1982\end{array}$ & 2000 & $\begin{array}{l}\text { 4-7; U.S.A. Japan; } \\
\text { Western Europe }\end{array}$ \\
\hline JAERI & $\begin{array}{l}\text { Japan Atomic Energy Research } \\
\text { Institute, March } 1983\end{array}$ & 2010 & Japan \\
\hline LEOB & $\begin{array}{l}\text { J.J. Schmidt, University of Mining } \\
\text { and Metallurgy, Leoben, } 1983\end{array}$ & 2010 & 8 \\
\hline LOVNS & $\begin{array}{l}\text { A. and H. Lovins, Rocky Mountain } \\
\text { Institute, June } 1982\end{array}$ & 2000 & 8 \\
\hline
\end{tabular}


Table A-2. IEW Poll Respondents (Continued)

\begin{tabular}{|c|c|c|c|}
\hline \multicolumn{2}{|c|}{ Organization/project } & \multirow{2}{*}{$\begin{array}{l}\text { Last Year } \\
\text { Reported } \\
2000\end{array}$} & \multirow{2}{*}{$\begin{array}{c}\text { Country/Region } \\
\text { Coverage }\end{array}$} \\
\hline MERZ & $\begin{array}{l}\text { N. Merzagora, Economic Analysis } \\
\text { Division, ENEA, June } 1983\end{array}$ & & \\
\hline MKR & $\begin{array}{l}\text { S.K. Mukherjee and S.H. Rahman, } \\
\text { November } 1982\end{array}$ & 2000 & India \\
\hline NGODP & $\begin{array}{l}\text { International Natural Gas Study, } \\
\text { Harvard University, and the } \\
\text { OPEC Downstream Project, } \\
\text { East-West Center, B. Mossavar- } \\
\text { Rahmani and F. Fesharaki, } 1983\end{array}$ & 1990 & $\begin{array}{l}\text { 5; Algeria, Ecuador, } \\
\text { Gabon, Indonesia, } \\
\text { Iran, Iraq, Kuwait, } \\
\text { Libya, Nigeria, } \\
\text { Qatar, Saudi } \\
\text { Arabia, United } \\
\text { Arab Emirates, } \\
\text { Venezuela }\end{array}$ \\
\hline NRMPE & $\begin{array}{l}\text { Norwegian Royal Ministry of Petro- } \\
\text { leum and Energy, } 1982\end{array}$ & 1990 & Norway \\
\hline NZMOE & $\begin{array}{l}\text { New Zealand Ministry of Energy, } \\
\text { August } 1982\end{array}$ & 2010 & New Zealand \\
\hline OBENA, OBENB & $\begin{array}{l}\text { Observatoire de L'Energie-Scen- } \\
\text { arios A and B, January } 1983\end{array}$ & 2000 & France \\
\hline OEWAG & $\begin{array}{l}\text { Österreichische Elektrizitätswirt- } \\
\text { shafts-AG (Austrian Electric } \\
\text { Company), } 1982\end{array}$ & 2000 & Austria \\
\hline OLADA, OLADB & $\begin{array}{l}\text { Organización Latinoamericana de } \\
\text { Energía (OLADE) - Scenarios A } \\
\text { and B, } 1983\end{array}$ & 2000 & Latin America \\
\hline OPECD, OPECL & $\begin{array}{l}\text { Organization of Petroleum Export- } \\
\text { ing Countries (OPEC)- } \\
\text { Domestic Energy Requirements } \\
\text { and Long-Term Energy Models, } \\
1983 \text { (forthcoming). }\end{array}$ & 2010 & $4-7$ \\
\hline ORIEA & $\begin{array}{l}\text { Oak Ridge Institute for Energy } \\
\text { Analysis, } 1982\end{array}$ & 2000 & $1-8$ \\
\hline PAEC & $\begin{array}{l}\text { Pakistan Atomic Energy Commis- } \\
\text { sion, December } 1982\end{array}$ & 2010 & Pakistan \\
\hline PAR & $\begin{array}{l}\text { J. Parikh, International Institute } \\
\text { for Applied Systems Analysis, } \\
1982\end{array}$ & 2010 & India \\
\hline PIEEM & $\begin{array}{l}\text { Potential for Industrial Expansion } \\
\text { Energy Model; Energy Studies } \\
\text { Unit, University of Strathclyde, } \\
\text { Scotland, October } 1982\end{array}$ & 2010 & 8 \\
\hline PILOT & $\begin{array}{l}\text { PILOT Energy-Economic Model; } \\
\text { P. H. McAllister and J. C. Stone, } \\
\text { Stanford University, December } \\
1982\end{array}$ & 2010 & U.S.A. \\
\hline POLAS & $\begin{array}{l}\text { Energy Problems Committee, } \\
\text { Polish Academy of Sciences, July } \\
1982\end{array}$ & 2010 & Poland \\
\hline
\end{tabular}


Table A-2. IEW Poll Respondents (Continued)

\begin{tabular}{|c|c|c|c|}
\hline \multicolumn{2}{|l|}{ Organization/project } & \multirow{2}{*}{$\begin{array}{c}\text { Last Year } \\
\text { Reported } \\
2000\end{array}$} & \multirow{2}{*}{$\begin{array}{c}\begin{array}{c}\text { Country/Region } \\
\text { Coverage }\end{array} \\
3-7\end{array}$} \\
\hline RESPA & Respondent A, January 1983 & & \\
\hline RESPB & Respondent B, January 1983 & 2000 & $3-7$ \\
\hline RESPC & Respondent C, 1982 & 1990 & $4-7$ \\
\hline RESPH & Respondent H, 1983 & 2000 & Japan \\
\hline RESPI & Respondent I, 1983 & 2000 & $\begin{array}{l}\text { 7; U.S.A. Japan; } \\
\text { Developing Coun- } \\
\text { tries, Western } \\
\text { Europe }\end{array}$ \\
\hline SERI & $\begin{array}{l}\text { Solar Energy Research institute- } \\
\text { Lawrence Berkeley Laboratory, } \\
1981\end{array}$ & 2000 & U.S.A. \\
\hline SHELL & $\begin{array}{l}\text { Shell International, London, June } \\
1983\end{array}$ & 2000 & 7 \\
\hline SMIE1, SMIE2 & $\begin{array}{l}\text { Spanish Ministry of Industry and } \\
\text { Energy (MINER) - Scenarios } 1 \\
\text { and 2, } 1983\end{array}$ & 2000 & $\begin{array}{l}\text { 1,2, 8; Japan; } \\
\text { Western Europe, } \\
\text { U.S.A. and Canada, } \\
\text { Latin America, } \\
\text { Africa, Middle East, } \\
\text { Aggregate of South } \\
\text { Asia, Southeast } \\
\text { Asia, and Austral- } \\
\text { asia }\end{array}$ \\
\hline SMIL & $\begin{array}{l}\text { V. Smil, University of Manitoba, } \\
1983\end{array}$ & 2010 & 2,8 \\
\hline SOHN & $\begin{array}{l}\text { I. Sohn, New York University, } \\
\text { December } 1982\end{array}$ & 2000 & $1-8$ \\
\hline STOHS, STOLS & $\begin{array}{l}\text { R. Stobaugh-high-and low- } \\
\text { energy supply cases, May } 1982\end{array}$ & 2000 & $4-6$ \\
\hline SWEA & Swedish Energy Agency, June 1983 & 2000 & 4 \\
\hline TEA & $\begin{array}{l}\text { J. Brady, National Board for } \\
\text { Science and Technology, Ireland, } \\
\text { April/May } 1983\end{array}$ & 2010 & Ireland \\
\hline $\begin{array}{l}\text { TRAC1, TRAC2, } \\
\text { TRAC3 }\end{array}$ & $\begin{array}{l}\text { Tractionel-Scenarios 1, 2, and } 3 \text {, } \\
\text { July } 1982\end{array}$ & 1995 & Belgium \\
\hline UNIDO & $\begin{array}{l}\text { United Nations Industrial Develop- } \\
\text { ment Organization (UNIDO), } \\
\text { February } 1983\end{array}$ & 1990 & $\begin{array}{l}\text { 2; Japan; North } \\
\text { America, Western } \\
\text { Europe, Eastern } \\
\text { Europe, Latin } \\
\text { America }\end{array}$ \\
\hline WBK & World Bank, July 1982 & 2000 & $1-8$ \\
\hline WECHG, WECLG & $\begin{array}{l}\text { World Energy Conference (WEC) } \\
\text {-Preliminary projections, } 1983 \\
\text { (forthcoming) }\end{array}$ & 2000 & $\begin{array}{l}3,7,8 ; \text { Developing } \\
\text { Countries }(5+6)\end{array}$ \\
\hline $3 R T$ & $\begin{array}{l}\text { 3RT Model; A.S. Manne and P.V. } \\
\text { Preckel, Stanford University, } \\
\text { March } 1983\end{array}$ & 2000 & $4-7$ \\
\hline
\end{tabular}

